\title{
Governance and Legitimation in the Transition to Nordic Electric Mobility
}

\author{
Benjamin Sovacool
}

\begin{abstract}
The chapter draws from empirical data collected across Denmark, Finland, Iceland, Norway, and Sweden to examine some of the differing policy regimes and electric mobility pathways in the Nordic region, especially for electric vehicles (EVs). The chapter identifies emerging crises of contestation, accountability, and participation, and it considers whether electric mobility entrenches or challenges automobility. This last point is not a given, with EVs in some situations leading to greater amounts of driving and shifting mobility practices towards automobility, yet in others, EVs seem to promote more sustainable patterns of transport as well as shifts in values. The chapter lastly offers possible policy suggestions for a more just and equitable transition.
\end{abstract}

Keywords Electric vehicles $\bullet$ Electric mobility $\bullet$ Sociotechnical transitions $\bullet$ Social acceptance $\bullet$ Automobility

B. Sovacool $(\bowtie)$

Science Policy Research Unit, University of Sussex, Falmer, UK e-mail: b.sovacool@sussex.ac.uk

(C) The Author(s) 2020

S. Sareen (ed.), Enabling Sustainable Energy Transitions, https://doi.org/10.1007/978-3-030-26891-6_7 


\subsection{INTRODUCTION}

Conventional forms of automobility, with their dependence on privatelyowned, petroleum-powered vehicles used primarily by single occupants, are a significant source of major social ills including traffic jams and accidents, climate change, air pollution, and negative impacts on land use (Urry 2004). For example, the World Health Organization (2018a) estimates that every year 1.25 million people are killed and 20-50 million injured in traffic road crashes involving cars or motorcycles; globally, road traffic injuries are also the leading cause of death for those between the age of 15 and 29 years. In the realm of climate change, the Intergovernmental Panel on Climate Change (IPCC) notes that the transport sector produces about 7 billion tonnes of direct greenhouse gas emissions each year, making it responsible for almost one-quarter $(23 \%)$ of total energy-related carbon dioxide equivalent emissions (Sims et al. 2014). With regard to ambient air pollution, emissions of particulate matter and other hazardous pollutants from road traffic contribute to hundreds of thousands of premature deaths each year (World Health Organization 2018b). Even in Europe, some 40 million people across 115 of the largest cities in the European Union are exposed to air exceeding health guidelines (for at least one pollutant); in particular, children who reside close to roads with heavy-duty vehicle traffic have twice the risk of respiratory problems as those living near less congested streets (World Health Organization 2018b).

The race for more sustainable forms of passenger mobility has, therefore, commenced, with innumerable policymakers and other stakeholders exploring electric mobility and electric vehicles (EVs) as a promising pathway. This chapter draws on extensive empirical research in the five Nordic countries-Denmark, Finland, Iceland, Norway, and Sweden-looking at the transition to electric mobility there, as part of a project known as Nordic Vehicle-to-Grid, or NV2G (Noel et al. 2019b). This data includes:

- 257 expert interview participants across 17 cities in Denmark, Finland, Iceland, Norway, and Sweden (almost one million words of transcribed text) (Sovacool et al. 2018b, c);

- Eight focus groups in Aarhus, Bergen, Copenhagen, Gothenburg, Helsinki, Reykjavik, Stockholm, and Tampere (Noel et al. 2019c);

- A representative survey of 5000+ adult participants (Sovacool et al. 2018a) as well as an online choice experiment of preferences (Noel et al. 2019a); 
- 126 visits to car dealerships across the Nordic region (Zarazua de Rubens et al. 2018);

- Scenarios and simulations to capture co-benefits and determine systems optimisation (Noel 2017; Noel et al. 2017, 2018);

- Content analysis of standards for charging and grid interaction (Kester et al. 2019).

The chapter draws from this data to examine some of the differing policy regimes and electric mobility pathways in the Nordic region; identify emerging crises of contestation, accountability, and participation; consider whether electric mobility entrenches or challenges automobility; and offer possible policy suggestions for a more just and equitable transition.

\subsection{Differing Policy Regimes and Sociotechnical Pathways in the Nordic Region}

Within the transport studies literature, an abundance of terms are often used to describe electric mobility, including eco-mobility, electric vehicles, and micro-mobility (when referring to smaller cars or e-bikes and scooters). For the purposes of our project, we defined electric mobility as any form of mobility that uses energy drawn from the electric power grid, storing it on board for propulsion (She et al. 2017). This definition encompasses electric vehicles of all varieties-battery electric vehicles, plug-in hybrid electric vehicles, fuel-cell electric vehicles, and so on-but also electric bikes and scooters as well as the occasional trucks for freight or buses.

Despite this broad definition, the most popular form of electric mobility in the Nordic region remains the passenger electric vehicle, or EV. According to Kester et al. (2018), the Nordic countries do indeed have very different regimes for automobility and thus EVs and electric mobility. As Table 7.1 overviews, these differences begin with electricity markets, with Iceland not belonging to Nord Pool and great variation in the other four countries for consumers in terms of various fixed and flexible schemes, including an increasing number of hourly flexible plans based on the Nord Pool spot market. These differences on the electricity side continue on the respective car markets. The geography and differing income levels seems to lead to different car turnover rates ranging from 8.5 to almost 13 years. Regarding EVs, the countries have radically distinct levels of EV incentive programmes and markets. The all-inclusive 


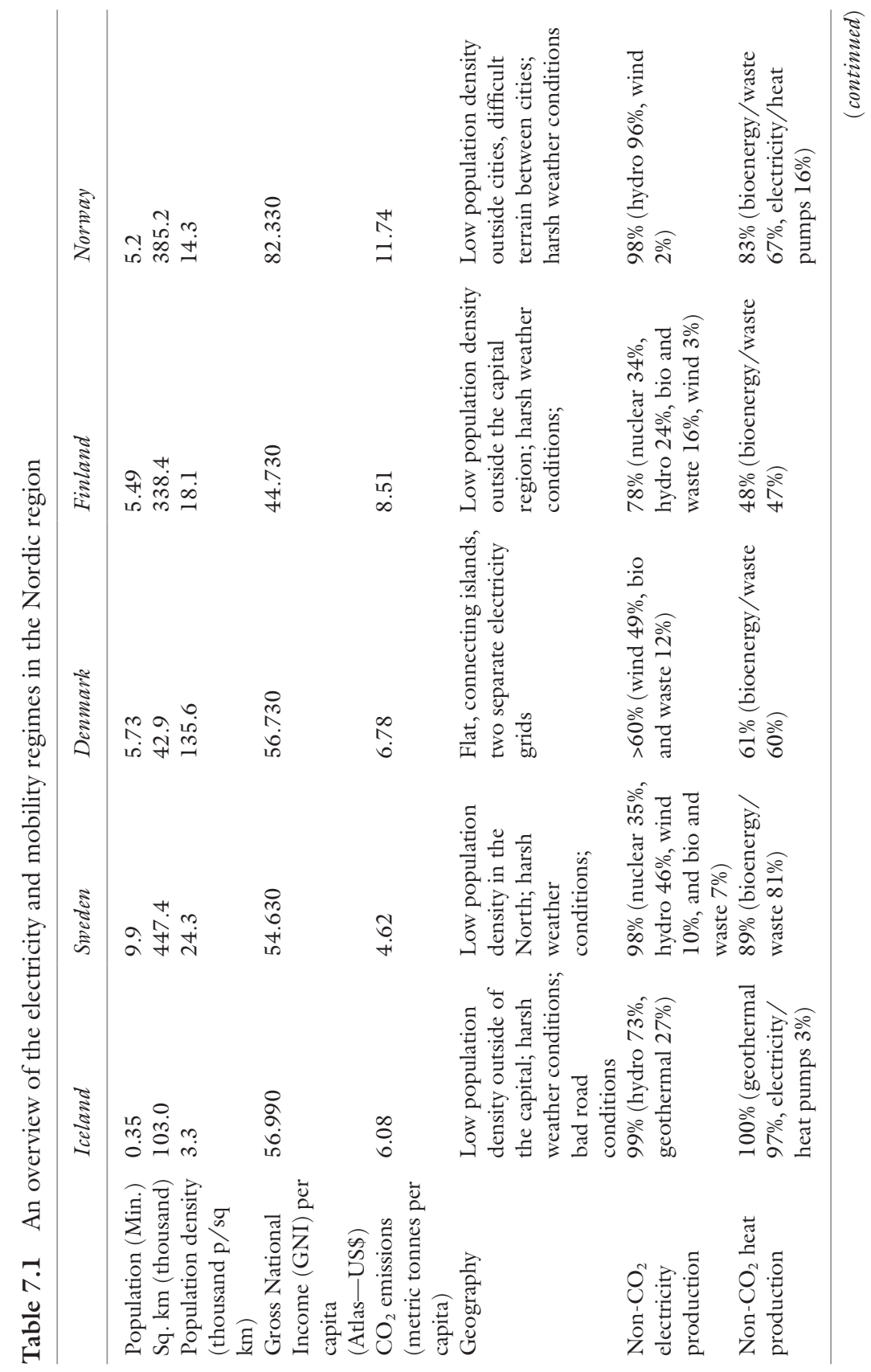




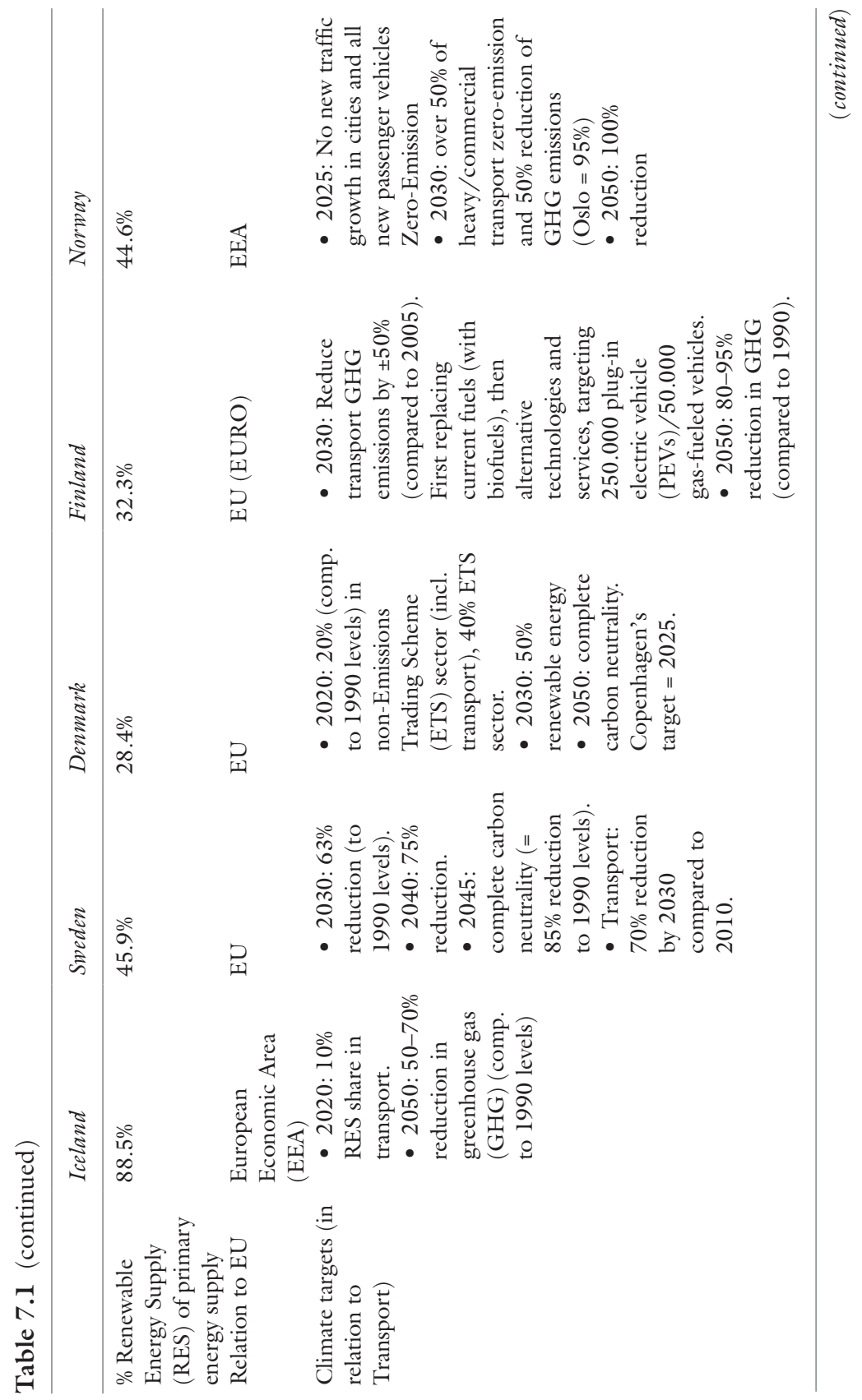




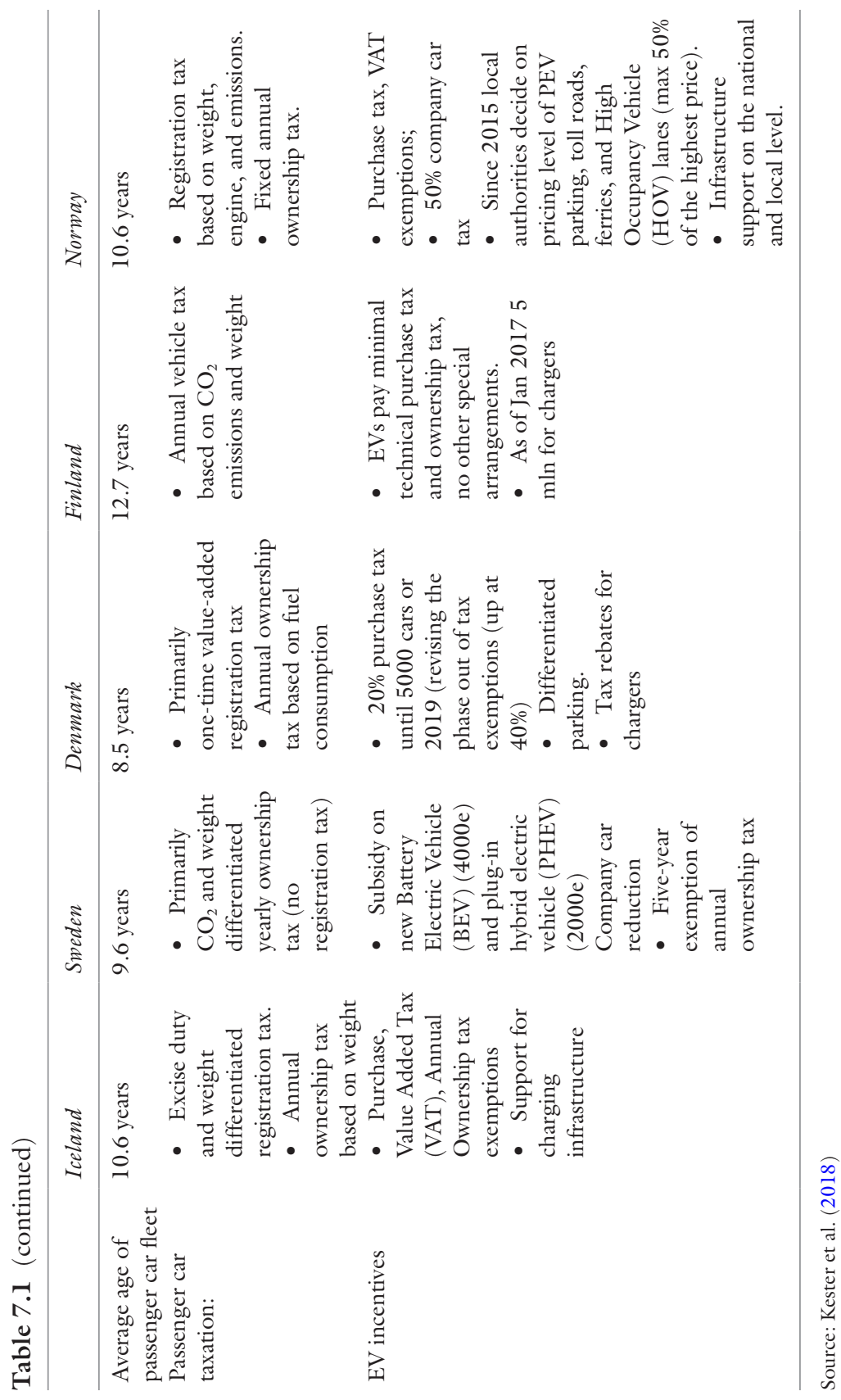


programmes of Norway are well known, but Iceland is also offering strong tax reductions, Sweden offers a cash subsidy (as it has fewer car taxes to reduce), Denmark recently halted the phase out of its earlier strong tax reductions for EVs (currently at $40 \%$ instead of $150 \%$ ) in an attempt to reinvigorate its $\mathrm{EV}$ sales and consumer trust in EVs, and in the case of Finland the EV incentives are fairly recent, in part due to Finnish comparative advantage in biofuels.

As Fig. 7.1 shows, these different support schemes are reflected in a different uptake of EVs as they lead to lower-in some cases competitive-consumer prices and time savings. And while Denmark stands out with its wind energy production, Norway stands out with its generous EV incentives, Finland has a large biofuel industry, and Sweden is the only country with a domestic automobile industry. All in all, the Nordic countries are different enough so that many of the major questions around electric mobility and vehicle-to-grid (V2G) come up, while they simultaneously offer flexible and modern electricity systems and a serious political concern about smog (Norway), oil imports (Iceland), and climate change (all of them) to take these developments seriously.

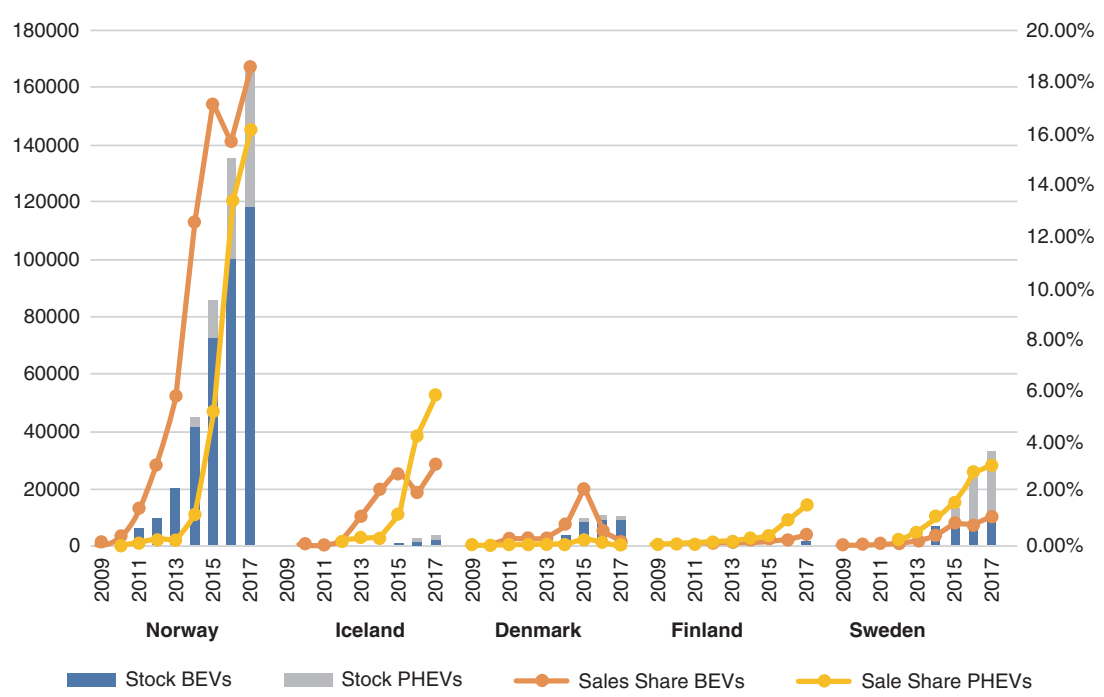

Fig. 7.1 Diffusion of electric vehicles in the five Nordic countries, 2009 to 2017. (Source: Kester et al. 2018) 
The Nordic region is thus a clear-cut example of where the transition to electric mobility is underway. For example, the International Energy Agency (2018) notes that across the five Nordic countries, the total stock of EVs reached 250,000 cars at the end of 2017 and accounted for $8 \%$ of the global total, the third-largest share after China and the United States. The per capita diffusion of EVs across the Nordic region is highest in the world at $10.6 \%$; the growth rate the highest in the world (up 57\% from the previous year); and Norway in particular features a 39\% market share of electric cars sales.

\subsection{Contests over Fairness, Participation, Environmental Governance, and Vulnerability}

However, even though the Nordic transition is underway, it has not been without its crises and contestations. Drawing from the empirical data from the NV2G project presented in Sovacool et al. (2019), this section explores these four challenges: inequitable access to EVs, exclusion and elitism in national planning, the creation of global externalities, and the worsening of some social vulnerabilities.

By far the most frequently mentioned injustice attribute across the entire sample of interview statements was that access to electric mobility technologies are not distributed evenly across Nordic society. As one respondent put it succinctly:

The most common EV in the Nordic Region is a Tesla. That's only for rich people and companies. It is not a mainstream car, it is not for everyone. It is a beautiful car, cool to have. But almost nobody can afford to.

Another was more elaborate in their reflection and highlighted the equity and justice challenge with electric mobility:

Tesla owners in Norway on average have a quite high income. The Tesla is not their only car, they can have it as maybe their second or third or fourth or fifth car. It's the wealthy getting in front of the common people so they can just pass them in the queue in the morning, and that's irritating ... A recent newspaper found that the typical, single Tesla Model X owner received subsidies in 2016 worth the same amount you can hand out to provide 30,000 trips on the buses and the subway system of Oslo. 
If accurate, such a statement even quantifies the equity issues, placing a single EV adopter above the needs of thousands of public transport users-it privileges one "wealthy" person over 30,000 potential "common people."

In the domain of energy democracy and public participation, respondents raised concerns that EVs only created (or were backed by) exclusionary policies and reflected elitism in national planning and policymaking. Essentially, these comments draw on or connect with some of the distributive justice issues mentioned above, such as equity, but relate it back to procedures and the regulatory process. In this way, issues of unfair access and elitism become reflected and entrenched in policy, which then further perpetuate inequity across mobility systems. For instance, one respondent suggested that:

In the beginning, I thought the negative reactions to Teslas was related to envy or jealousy. But after thinking more about it, it's a rational and emotional reaction. Why should we lose a lot of money for rich people getting a cheap, expensive, luxury car? The politicians ... are [being] controlled.

Another framed this as a procedural justice issue about policy, rather than one purely of distributive justice:

People see EVs as only for the upper class. They find them very unfair. To the politicians, electric mobility sounds very good and they remain convinced that EVs can help store energy, decarbonize transport, and balance the grid.

Yet another elaborated that:

In Finland, government policy for EVs has been socially catastrophic, because only rich people buy new Teslas (laughs).

Other respondents mentioned the problem as one of "politicians prioritising between hundreds of goals," and perhaps lacking the "political will" to make controversial decisions or challenge entrenched interest.

At another level, respondents mentioned that the widespread adoption of electric mobility systems, especially in a vehicle-to-grid (V2G) configuration, could potentially erode democratic processes, and undermine people's autonomy or liberty. One respondent, for example, noticed a reluctance among consumers to "become dependent on some distant 
infrastructure for their daily travel." Another illustrated another part of the logic of this vision when noting "people are afraid that the batteries will not last long enough and it is very costly to get new ones." This last statement underscores the potential for a V2G system to become more easily controlled by profiteering companies-creating an exclusionary innovation system or policy regime.

The global externality issues connected to electric mobility largely touch on externalities - in various domains (environmental, community, market) and scales (local, national, global). In the environmental domain, some literature has noted that EVs, in particular, can lead to externalities such as greenhouse gas emissions from electricity use, toxic pollution from battery manufacturing and disposal, and water consumption. In terms of climate change, for EVs to actually deliver well-to-wheels carbon reductions, the carbon content of electric power generation must be low. Otherwise, EVs will simply shift the exposure to air pollution away from urban areas and towards rural populations located closer to the power plants that provide electricity for recharging EV batteries in the city. One respondent offered an illustrative statement underscoring environmental concerns in the context of plug-in hybrid EVs. They noted:

The problem with plug-in hybrid EVs in the region is that they can switch between fossil fuels (gasoline or diesel) and all electric mode. Many of such cars are bought by rich people not bothering to plug it in, driving it in pure fossil mode all the time only to save 100,000 to 200,000 kroner in taxes. They buy the car but never intend to use the environmental package, so that's obvious that you need some scheme to stimulate the real zero emission driving.

In addition, some research has suggested that EVs shift pollution from local places and make it more regional; it also depends on local fuel mixes whether a net benefit to health or greenhouse gas emissions occur. Furthermore, the production of EVs requires equipment and material inputs that raise concerns about toxicity and recycling. Electric drivetrains, motors, and batteries need lithium, nickel, copper, and aluminium, as well as critical materials, somewhat harder to find, such as cobalt and indium. In this context, the possible environmental benefits of an electric mobility transition-fewer greenhouse gas emissions and improved air quality in urban environments-may come at the cost of greater pollution from factories making components and the landfills and junkyards where obsolete models end up. A final issue falls in the community domain, where externalities to greater electric mobility adoption include greater risk of 
accidents and traffic congestion, given that vehicles and e-bikes can still promote an automobility paradigm that transportation should be private, rather than public, and motorised rather than human-powered.

A final area of contestation relates to vulnerability, especially jobs (notably small and independent fuel providers and maintenance firms) and impacts on rural residents. In the Nordic region, many petrol and fuel stations would need to instal electric charging infrastructure, a prohibitively costly endeavour. Automotive dealerships and maintenance firms would also see a potentially large loss of revenue, as well as those selling alternatives to electric vehicles such as small-scale biofuel or hydrogen companies, a growing industrial segment at least in Denmark. Within Nordic automotive dealerships specifically, Zarazua de Rubens et al. (2018) found that salespersons generally articulate that EVs take a longer time to sell, take more effort to sell, and result in less revenue for maintenance-which can all result in negative impacts on profitability for automotive companies and dealerships, and consequently jobs, in the short term.

\subsection{Legitimating or Challenging Automobility?}

A deeper concern, separate from contests and challenges to accountability or equality, concerns whether EVs are in fact a radical, transformative innovation that challenges automobility, or an incremental, supportive innovation that only further entrenches it. In Table 7.2, for example, we show all of the positive and negative synergies electric mobility can have with sustainability. As that table highlights, electric mobility can potentially displace large amounts of carbon for passenger vehicles and even fleets, but also run the risk of further embedding motorised, private automobility as well as increased driving. Graham-Rowe et al. (2012) note for example that because adopters perceived their EVs to be more "environmentally-friendly," they drove them 1.64 times further than cars they did not see as "eco-cars." Some drivers even attempted to recharge their vehicles not by plugging in at home or at work, but by running the internal combustion engine and then using the re-generative braking system to "charge" their vehicle- "thereby negating the carbon savings" (Graham-Rowe et al. 2012: 148). This underscores that EVs can entrench automobility without necessarily decarbonising.

Part of this tension stems from the material, discursive and cultural elements that re-perform the core elements of the automobility regime. On 
Table 7.2 Positive and negative synergies with electric mobility and sustainability

\begin{tabular}{|c|c|c|}
\hline Dimension & $\begin{array}{l}\text { Reinforces sustainable } \\
\text { automobility }\end{array}$ & $\begin{array}{l}\text { Reinforces unsustainable } \\
\text { mobility }\end{array}$ \\
\hline Intermodality & $\begin{array}{l}\text { Use of EV within systems of } \\
\text { intermodality, in combination } \\
\text { with measures to discourage car } \\
\text { use }\end{array}$ & $\begin{array}{l}\text { Use of EV in systems that } \\
\text { encourage excessive driving } \\
\text { and EVs as second or third } \\
\text { (luxury) cars }\end{array}$ \\
\hline $\begin{array}{l}\text { Desire for motorised } \\
\text { transport }\end{array}$ & Substitution of cars and scooters & Increase in car-based mobility \\
\hline Organised car sharing & $\begin{array}{l}\text { Use of EVs in car sharing/ } \\
\text { ride-sharing schemes }\end{array}$ & $\begin{array}{l}\text { Increase in preferences for } \\
\text { private, single-occupancy } \\
\text { driving practices }\end{array}$ \\
\hline Increases in mobility & $\begin{array}{l}\text { Implemented in tandem with } \\
\text { active transport planning } \\
\text { (walking, cycling) }\end{array}$ & $\begin{array}{l}\text { Extra car trips, multiple car } \\
\text { ownership, displaces } \\
\text { enthusiasm for cycling }\end{array}$ \\
\hline $\begin{array}{l}\text { Zero-carbon and low } \\
\text { carbon electricity }\end{array}$ & $\begin{array}{l}\text { Use of EV in countries with } \\
\text { decarbonised electricity grids }\end{array}$ & $\begin{array}{l}\text { Use of EV in countries with } \\
\text { coal-based electricity }\end{array}$ \\
\hline Smart grids & $\begin{array}{l}\text { Charging at off-peak times and } \\
\text { storage for peak demand }\end{array}$ & $\begin{array}{l}\text { Charging at peak times with } \\
\text { no storage }\end{array}$ \\
\hline $\begin{array}{l}\text { Critical materials } \\
\text { scarcity }\end{array}$ & $\begin{array}{l}\text { Efficient manufacturing } \\
\text { techniques with an appreciation } \\
\text { for externalities with battery } \\
\text { recycling }\end{array}$ & $\begin{array}{l}\text { Inefficient and polluting } \\
\text { manufacturing techniques with } \\
\text { no battery recycling }\end{array}$ \\
\hline $\begin{array}{l}\text { Employment, } \\
\text { competitiveness, and } \\
\text { growth }\end{array}$ & $\begin{array}{l}\text { Designed and promoted by } \\
\text { sustainable firms with a focus on } \\
\text { innovation and entrepreneurship }\end{array}$ & $\begin{array}{l}\text { Coopted and marginalised by } \\
\text { transnational conglomerates } \\
\text { with little desire for social } \\
\text { change }\end{array}$ \\
\hline
\end{tabular}

Source: Sovacool (2017)

Note: $\mathrm{EV}=$ Electric vehicle

both landscape and regime level, for example, the system locks itself in through constructed infrastructure, traffic rules and regulations, expertise (in terms of personnel and beliefs), travel routines, cultural values around enjoyment, status and freedom, and incumbent industries.

\subsection{Policy Suggestions for a More Just and Sustainable Transition}

Nonetheless, the sustainability credentials of EVs can be captured by an aggressive and proactive policy. If EVs are determined by policymakers to play an essential role in national climate change mitigation plans, our data 
suggests several policies to prevent or at least minimise injustice in Table 7.3. Thus, our justice framework shows that policymakers need to think broadly when implementing EVs in order to avoid half-measures of energy justice.

In addition, many of the areas of contestation, or the issues of equity and vulnerability that arise, are not "new" to EVs or V2G-they likely exist with other low carbon technologies and also conventional cars and other forms of mobility. However, a lesson here is perhaps that changing the perfor-

Table 7.3 Policy mechanisms for more sustainable and just Nordic electric mobility

\begin{tabular}{|c|c|c|}
\hline $\begin{array}{l}\text { Area of } \\
\text { contestation }\end{array}$ & Example(s) & Policy response \\
\hline Unfair access & $\begin{array}{l}\text { EVs only accessible by } \\
\text { higher socioeconomic } \\
\text { consumers }\end{array}$ & $\begin{array}{l}\text { Avoid regressive EV subsidies, encourage } \\
\text { lower-cost EV development, increase } \\
\text { consumer knowledge of cheaper EVs }\end{array}$ \\
\hline $\begin{array}{l}\text { Elitism in } \\
\text { planning and } \\
\text { policymaking }\end{array}$ & $\begin{array}{l}\text { EV policy determined in } \\
\text { scope of higher } \\
\text { socioeconomic consumers } \\
\text { Exclusion of other subsets } \\
\text { of the population (low } \\
\text { income, users of other } \\
\text { mobility) }\end{array}$ & $\begin{array}{l}\text { Better inclusion of the entire population in } \\
\text { EV policies (e.g. public charging } \\
\text { infrastructure coverage), } \\
\text { Broader electrification of public transport, } \\
\text { more comprehensive transport policy, } \\
\text { progressive EV, and V2G subsidies }\end{array}$ \\
\hline $\begin{array}{l}\text { Lifecycle } \\
\text { externalities }\end{array}$ & $\begin{array}{l}\text { EVs exacerbate other } \\
\text { externalities (congestion, } \\
\text { electricity-related } \\
\text { externalities) } \\
\text { Global south excluded } \\
\text { from EVs, instead get } \\
\text { cheap petrol/diesel }\end{array}$ & $\begin{array}{l}\text { Deployment of EVs requires deployment of } \\
\text { other renewable electricity, transportation } \\
\text { planning policies, internalising externalities, } \\
\text { carefully managing battery and lifecycle waste } \\
\text { streams } \\
\text { Shift international focus of EVs beyond } \\
\text { global North, international mechanisms to } \\
\text { shift technology and support small EV } \\
\text { initiatives present in those countries (clean } \\
\text { development mechanism policy) }\end{array}$ \\
\hline $\begin{array}{l}\text { Vulnerable } \\
\text { groups }\end{array}$ & $\begin{array}{l}\text { Conventional car industry } \\
\text { job loss, particularly } \\
\text { maintenance } \\
\text { Dealership resistance to } \\
\text { selling new technologies }\end{array}$ & $\begin{array}{l}\text { Implement job training programmes for new } \\
\text { EV industry (e.g. battery specialisation, } \\
\text { EVSE repair, V2G aggregation) similar to } \\
\text { coal-to-solar transition } \\
\text { Consistent EV and V2G policy signals, } \\
\text { allowing industry preparation and investment } \\
\text { for EV transition }\end{array}$ \\
\hline
\end{tabular}

Source: Sovacool et al. (2019)

Note: $\mathrm{EV}=$ Electric vehicle, $\mathrm{V} 2 \mathrm{G}$ = Vehicle-to-grid, EVSE = Electric vehicle supply equipment 
mance or engine of a vehicle, or introducing a new type of car such as an $\mathrm{EV}$ or an innovation such as $\mathrm{V} 2 \mathrm{G}$, does not necessarily change the underlying political economy or power dynamics behind mobility or automobility. Systems of mobility themselves-involving multiple, competing and overlapping technologies, modes of mobility, and transport infrastructurescan also be just or unjust, even if they utilise innovations such as EVs or $\mathrm{V} 2 \mathrm{G}$ that have material potential to reduce environmental and social harms. There may be situations, practices, or socio-material configurations where V2G EVs meet principles of justice, sustainability, or sustainable development, but also areas where they may not (such as when an EV reinforces automobility and merely represents an additional car, and thus becomes a net environmental burden, or increases the demand for motorised mobility at the expense of more active walking and cycling). The sociotechnical potential of electric mobility is, therefore, situational, relational, and contingent. The answer to the question "Is it good?" will invariably be "It depends." The chapter has aimed to provide an overview of what it depends on, to inform an accountable and sustainable energy transition.

\subsection{Conclusion}

To conclude, the inherent promise embodied in electric mobility is just that, potential not yet fully realised. Its regional and perhaps even global deployment pathways, its future potential or vision, will differ considerably depending on context and policy. Electric mobility is at a pivotal moment in its development where it could merely reinforce aspects of conventional mobility-where society instead adopts more efficient conventional cars, or other alternative modes and fuels such as biofuel or hydrogen. Or, electric mobility could remain trapped as a niche, an important but by no means dominant system of mobility. Alternatively, perhaps electric mobility will reach high penetrations across a dirty grid, a decarbonised grid, or a super-smart high-tech digitised grid. Which of these pathways becomes a reality is contingent and context-specificwhich reveals the promise, but also the peril, of electric mobility.

\section{REFERENCES}

Graham-Rowe, E., Gardner, B., Abraham, C., Skippon, S., Dittmar, H., Hutchins, R., \& Stannard, J. (2012). Mainstream consumers driving plug-in batteryelectric and plug-in hybrid electric cars: A qualitative analysis of responses and evaluations. Transportation Research Part A: Policy and Practice, 46, 140-153. 
International Energy Agency. (2018). Nordic EV outlook 2018: Insights from leaders in electric mobility. Paris: OECD.

Kester, J., Noel, L., Lin, X., Zarazua de Rubens, G., \& Sovacool, B. K. (2019, January). The coproduction of electric mobility: Selectivity, conformity and fragmentation in the sociotechnical acceptance of vehicle-to-grid (V2G). Journal of Cleaner Production, 207, 400-410.

Kester, J., Noel, L., Zarazua de Rubens, G., \& Sovacool, B. K. (2018, May). Promoting vehicle to grid (V2G) in the Nordic region: Expert advice on policy mechanisms for accelerated diffusion. Energy Policy, 116, 422-432.

Noel, L. (2017). The hidden economic benefits of large-scale renewable energy deployment: Integrating heat, electricity and vehicle systems. Energy Research \&. Social Science, 26, 54-59.

Noel, L., Brodie, J., Kempton, W., Archer, C., \& Budischak, C. (2017). A cost minimization model of electricity production and transportation with considerations of externalities. Applied Energy, 189, 110-121.

Noel, L., Zarazua de Rubens, G., \& Sovacool, B. K. (2018, June). Optimizing innovation, carbon and health in transport: Assessing socially optimal electric mobility and vehicle-to-grid (V2G) pathways in Denmark. Energy, 153, 628-637.

Noel, L. D., Carrone, A. P., Jensen, A. F., Zarazua, G. D. R., Kester, J., \& Sovacool, B. K. (2019a, February). Willingness to pay for electric vehicles and vehicle-to-grid applications: A Nordic choice experiment. Energy Economics, $78,525-534$.

Noel, L., Kester, J., Zarazua de Rubens, G., \& Sovacool, B. K. (2019b). Vebicleto-grid: A sociotechnical transition beyond electric mobility. Basingstoke: Palgrave Macmillan.

Noel, L. D., Zarazua de Rubens, G., Sovacool, B. K., \& Kester, J. (2019c, February). Fear and loathing of electric vehicles: The reactionary rhetoric of range anxiety. Energy Research \& Social Science, 48, 96-107.

She, Z.-Y., Sun, Q., Ma, J.-J., \& Xie, B.-C. (2017). What are the barriers to widespread adoption of battery electric vehicles? A survey of public perception in Tianjin, China. Transport Policy, 56, 29-40.

Sims, R., Schaeffer, R., Creutzig, F., Cruz-Núñez, X., D’Agosto, M., Dimitriu, D., ... Tiwari, G. (2014). Transport. In O. Edenhofer, R. Pichs-Madruga, Y. Sokona, E. Farahani, S. Kadner, K. Seyboth, A. Adler, I. Baum, S. Brunner, P. Eickemeier, B. Kriemann, J. Savolainen, S. Schlömer, C. von Stechow, T. Zwickel, \& J. C. Minx (Eds.), Climate change 2014: Mitigation of climate change. Contribution of Working Group III to the Fifth Assessment Report of the Intergovernmental Panel on Climate Change. Cambridge, UK and New York, NY: Cambridge University Press.

Sovacool, B. K. (2017, May). Experts, theories, and electric mobility transitions: Toward an integrated conceptual framework for the adoption of electric vehicles. Energy Research \& Social Science, 27, 78-95. 
Sovacool, B. K., Kester, J., Noel, L., \& Zarazua de Rubens, G. (2018a, September). The demographics of decarbonizing transport: The influence of gender, education, occupation, age, and household size on electric mobility preferences in the Nordic region. Global Environmental Change, 52, 86-100.

Sovacool, B. K., Kester, J., Zarazua de Rubens, G., \& Noel, L. (2018b, April). Expert perceptions of low-carbon transitions: Investigating the challenges of electricity decarbonisation in the Nordic region. Energy, 148, 1162-1172.

Sovacool, B. K., Noel, L., Zarazua de Rubens, G., \& Kester, J. (2018c, December). Reviewing Nordic transport challenges and climate policy priorities: Expert perceptions of decarbonisation in Denmark, Finland, Iceland, Norway, Sweden. Energy, 165, 532-542.

Sovacool, B. K., Noel, L. D., Zarazua de Rubens, G., \& Kester, J. (2019, March). Energy injustice and Nordic electric mobility: Inequality, elitism, and externalities in the electrification of vehicle-to-grid (V2G) transport. Ecological Economics, 157, 205-217.

Urry, J. (2004). The 'system' of automobility. Theory, Culture \& Society, 21, 25-39. World Health Organization. (2018a). Road traffic injuries: Key facts, February 19. Retrieved from http://www.who.int/news-room/fact-sheets/detail/ road-traffic-injuries

World Health Organization. (2018b). Air pollution and climate change. Retrieved from http://www.euro.who.int/en/health-topics/environment-and-health/ Transport-and-health/data-and-statistics/air-pollution-and-climate-change2

Zarazua de Rubens, G., Noel, L., \& Sovacool, B. K. (2018, June). Dismissive and deceptive car dealerships create barriers to electric vehicle adoption at the point of sale. Nature Energy, 3, 501-507.

Open Access This chapter is licensed under the terms of the Creative Commons Attribution 4.0 International License (http://creativecommons.org/licenses/ by $/ 4.0 /$ ), which permits use, sharing, adaptation, distribution and reproduction in any medium or format, as long as you give appropriate credit to the original author(s) and the source, provide a link to the Creative Commons licence and indicate if changes were made.

The images or other third party material in this chapter are included in the chapter's Creative Commons licence, unless indicated otherwise in a credit line to the material. If material is not included in the chapter's Creative Commons licence and your intended use is not permitted by statutory regulation or exceeds the permitted use, you will need to obtain permission directly from the copyright holder.

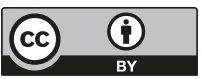

